\title{
Neurogenin 3 is regulated by neurotrophic tyrosine kinase receptor type 2 (TRKB) signaling in the adult human exocrine pancreas
}

\author{
Michael J. Shamblott ${ }^{1,2^{*}}$, Marci L. O’Driscoll' ${ }^{1}$ Danielle L. Gomez ${ }^{1}$ and Dustin L. McGuire ${ }^{1}$
}

\begin{abstract}
Background: Reports of exocrine-to-endocrine reprogramming through expression or stabilization of the transcription factor neurogenin 3 (NGN3) have generated renewed interest in harnessing pancreatic plasticity for therapeutic applications. NGN3 is expressed by a population of endocrine progenitor cells that give rise exclusively to hormone-secreting cells within pancreatic islets and is necessary and sufficient for endocrine differentiation during development. In the adult human pancreas, NGN3 is expressed by dedifferentiating exocrine cells with a phenotype resembling endocrine progenitor cells and the capacity for endocrine differentiation in vitro. Neurotrophic tyrosine kinase receptor type 2 (TRKB), which regulates neuronal cell survival, differentiation and plasticity, was identified as highly overexpressed in the NGN3 positive cell transcriptome compared to NGN3 negative exocrine cells. This study was designed to determine if NGN3 is regulated by TRKB signaling in the adult human exocrine pancreas.
\end{abstract}

Methods: Transcriptome analysis, quantitative reverse transcriptase polymerase chain reaction (RTPCR) and immunochemistry were used to identify TRKB isoform expression in primary cultures of human islet-depleted exocrine tissue and human cadaveric pancreas biopsies. The effects of pharmacological modulation of TRKB signaling on the expression of NGN3 were assessed by Student's t-test and ANOVA.

Results: Approximately $30 \%$ of cultured exocrine cells and $95 \%$ of NGN3+ cells express TRKB on their cell surface. Transcriptome-based exon splicing analyses, isoform-specific quantitative RTPCR and immunochemical staining demonstrate that TRKB-T1, which lacks a tyrosine kinase domain, is the predominant isoform expressed in cultured exocrine tissue and is expressed in histologically normal cadaveric pancreas biopsies. Pharmacological inhibition of TRKB significantly decreased the percentage of NGN3+ cells, while a TRKB agonist significantly increased this percentage. Inhibition of protein kinase B (AKT) blocked the effect of the TRKB agonist, while inhibition of tyrosine kinase had no effect. Modulation of TRKB and AKT signaling did not significantly affect the level of NGN3 mRNA.

Conclusions: In the adult human exocrine pancreas, TRKB-T1 positively regulates NGN3 independent of effects on NGN3 transcription. Targeting mechanisms controlling the NGN3+ cell population size and endocrine cell fate commitment represent a potential new approach to understand pancreas pathobiology and means whereby cell populations could be expanded for therapeutic purposes.

Keywords: TRKB, NTRK2, Neurogenin 3, NGN3, Pancreas, Exocrine, Endocrine, AKT, Protein kinase B

\footnotetext{
* Correspondence: mshamblott@morphogenesis-inc.com

'Department of Pediatrics, Children's Research Institute, University of South

Florida Morsani College of Medicine, 601 4th St. South, CRI 3005, St.

Petersburg, FL 33701, USA

${ }^{2}$ Morphogenesis, Inc, 4613 N. Clark Ave, Tampa, FL 33614, USA
} 


\section{Plain English summary}

Neurogenin 3 (NGN3) is a transcription factor that is essential for development of endocrine hormoneproducing pancreatic islet cells. NGN3 also is expressed by dedifferentiated cells in the adult human exocrine pancreas that have begun to take on characteristics of endocrine progenitor cells during development. Neurotrophic tyrosine kinase receptor type 2 (TRKB), a cytokine receptor that promotes functional plasticity in cells of the developing and adult nervous system, was identified as being overexpressed by the NGN3+ cell population compared to NGN3- exocrine cells. In this report we demonstrate that NGN3+ cells in the adult human exocrine pancreas express TRKB-T1, an isoform that lacks a tyrosine kinase domain. Positive regulation of NGN3 protein by TRKB involves the cell-signaling molecule protein kinase $B(\mathrm{AKT})$. Blocking tyrosine kinase activity had no effect on the percentage of cells expressing NGN3 protein. Pharmacological methods that target the NGN3+ cell population size and endocrine cell fate commitment may be an approach to treat diabetes.

\section{Background}

The transcription factor neurogenin 3 (NGN3) is necessary and sufficient for islet specification during development [1-4]. NGN3 also is expressed by acinar and duct cells in histologically normal pancreas biopsies and in primary cultures of adult human exocrine tissue [5], but has not been detected in the adult rodent pancreas. NGN3+ cells isolated by coexpression of the cell surface glycoprotein CD133 from adult human exocrine tissue have a transcriptome consistent with exocrine-cell dedifferentiation, a phenotype that resembles endocrine progenitor cells during development and a capacity for endocrine differentiation in vitro [5]. Comparison of the NGN3+/CD133+ cell transcriptome to surrounding NGN3/CD133-depleted (NGN3D/CD133D) exocrine cells identified significant upregulation of neurotrophic tyrosine kinase receptor type 2 (NTRK2, referred to as TRKB) [5]. TRKB regulates neuronal cell function, differentiation, survival and plasticity [6-8] and is expressed in the pancreas $[9,10]$ and by pancreatic ductal adenocarcinoma cells [11-15]. The human TRKB gene encodes at least 100 unique transcripts and 10 protein isoforms with distinctive functional domains and downstream signaling pathways generated through alternate promoters, gene splicing and stop codon usage [16]. The full-length isoform (TRKB-FL) signals through a tyrosine kinase domain that leads to downstream activation of protein kinase $B$ (AKT) $[17,18]$, extracellular signal related kinase (ERK) $[19,20]$ and phospholipase $C[21,22]$. The TRKB-T1 isoform, which lacks a tyrosine kinase domain [23-26], can form heterodimers with TRKB-FL to reduce tyrosine kinase activity [27] or positively signal through the p75 low-affinity nerve growth factor receptor [28], AKT [29] or Rho guanine dissociation inhibitor and Rho/Rac GTPases [30, 31].

Here, we demonstrate that TRKB-T1 is the predominant isoform expressed in cultured adult human exocrine tissue and is coexpressed with NGN3 in cadaveric pancreas biopsies. In primary cultures of human exocrine tissue, the percentage of NGN3 + cells is positively regulated by TRKB signaling. Inhibition of AKT, but not tyrosine kinase, blocks the regulation of NGN3 by TRKB. TRKB-T1 signaling in NGN3+ cells may contribute to cellular dedifferentiation indicative of exocrine cell plasticity. As such, the mechanisms regulating NGN3 may provide insights into pancreas pathobiology and the therapeutic potential of this cell population.

\section{Methods}

\section{Primary exocrine tissue culture}

Islet-depleted cadaveric exocrine tissue and histologically normal biopsies from human pancreata of non-diabetic adult cadaver donors was obtained from ICR Basic Science Islet Distribution Program (IIDP) under the auspices of the National Institutes of Health National Center for Research Resources (NCRR). Written informed consent for research use was obtained by the institutions that collected the tissue. Tissues were received without personal identifiers. Exocrine tissue was received within $48 \mathrm{~h}$ post mortem and cultured at a density of $100 \mathrm{ml}$ media per $\mathrm{ml}$ of pelleted tissue in serum-free Miami Media 1A (Mediatech 98-021-CV, Manassas, VA, USA) supplemented with freshly prepared $0.01 \mathrm{~g} \mathrm{~L}^{-1}$ reduced glutathione. Tissue was plated in low-adhesion plastic dishes and maintained in suspension culture at $37{ }^{\circ} \mathrm{C}, 5 \% \mathrm{CO}_{2}$ for 4-6 days with media replacement every 2 days. Drugs were administered initially, at media replenishment and $1-2 \mathrm{~h}$ before harvest. Drugs and final dosages were: 7,8-dihydroxyflavone $(0.1 \mu \mathrm{M}$, Tocris Bioscience, Bristol, UK); N-[2-[[(Hexahydro-2-oxo-1Hazepin-3-yl)amino]carbonyl]phenyl]benzo[b]thiophene-2carboxamide (ANA-12, $50 \mu \mathrm{M}$, Tocris Bioscience, Bristol, UK); 4-Amino-5,8-dihydro-5-oxo-8- $\beta$-D-ribofuranosylpyrido[2,3-d]pyrimidine-6-carboxamide (API-1, $1 \mu \mathrm{M}$, Tocris Bioscience, Bristol, UK); (9S, 10S, 12R)2,3,9,10,11,12-Hexahydro-10-hydroxy-10-(hydroxymethyl)9-methyl-9,12-epoxy-1H-diindolo[1,2,3-fg:3,2,'1'-kl]pyrrolo [3,4-i] [1, 6]benzodiazocin-1-one (CEP-701, $10 \mathrm{nM}$, Sigma-Aldrich, St. Louis, MO, USA) and 5-(2-Phenylpyrazolo[1,5-a]pyridin-3-yl)-1H-pyrazolo[3,4-c]pyridazin3-ylamine (FR180204, $20 \mu \mathrm{M}$, Tocris Bioscience, Bristol, UK). All drugs were resuspended in dimethyl sulfoxide (DMSO). Drug dosages were the maximum possible without causing substantial cell death as determined by ethidium bromide exclusion and esterase activity (LIVE/ DEAD, Life Technologies, Carlsbad, CA, USA) and nuclear 
morphology. Replication (n) refers to biological replicate exocrine cultures.

\section{FACS analyses}

To measure expression of TRKB, live single cell suspensions of cultured exocrine tissue were stained with mouse anti-human TRKB (R\&D Systems, Minneapolis, MN, USA 1:20) or mouse IgG1 isotype negative control (BD Pharmingen, San Jose, CA, USA \#340761 1:10) in phosphate-buffered saline (PBS), $\mathrm{pH} 7.2,0.5 \%$ bovine serum albumin (BSA, Jackson ImmunoResearch, West Grove, PA, USA), and $2 \mathrm{mM}$ ethylenediaminetetraacetic acid (EDTA) for $30 \mathrm{~min}$ at $4{ }^{\circ} \mathrm{C}$. Cells were then washed and stained with anti-mouse Alexa Fluor-647 (Invitrogen, Carlsbad, CA, USA) for $30 \mathrm{~min}$ at $4{ }^{\circ} \mathrm{C}$.

To measure coexpression of TRKB and NGN3, cells were then fixed, blocked and permeabilized using Transcription Factor Buffer Set reagents (BD Pharmigen, San Jose, CA, USA) and stained with rabbit anti-human NGN3 (Sigma, St. Lois, MO, USA Prestige HPA039785, 1:500), or an equivalent concentration of rabbit Ig negative control, overnight at $4{ }^{\circ} \mathrm{C}$. NGN3 staining was detected with anti-rabbit Alexa Fluor-488 (Invitrogen, Carlsbad, CA, USA) secondary antibody for $30 \mathrm{~min}$ at $4{ }^{\circ} \mathrm{C}$. Cell populations were gated on FL1/SSC-A to identify the NGN3+ cell population and on FL4/SSC-A to identify the TRKB+ population. To quantify percentage of NGN3+ cells that are TRKB+, NGN3 gated cells were analyzed for TRKB expression in FL4. To quantify the percentage of TRKB+ cells that are NGN3+, TRKB gated cells were analyzed for NGN3 expression in FL1.

To measure coexpression of TRKB and CD133, cells were then stained with mouse anti-CD133-phycoerythrin (PE) (Miltenyi Biotec, San Diego, CA, USA 1:10) or mouse IgG2b-PE isotype negative control (BD Pharmingen, San Jose, CA, USA \#555743 1:10) for $10 \mathrm{~min}$ at $4{ }^{\circ} \mathrm{C}$. Staining for TRKB and anti-mouse secondary antibody prior to staining for CD133 with an antibody conjugated to PE was used to avoid cross-reactivity between the two mouse monoclonal primary antibodies. Cell populations were gated on FL2/SSC-A to identify the CD133+ population and on FL4/SSC-A to identify the TRKB+ population. To quantify the percentage of CD133+ cells that are TRKB+, CD133 gated cells were analyzed for TRKB expression in FL4. To quantify the percentage of TRKB+ cells that are CD133+, TRKB gated cells were analyzed for CD133 expression in FL2. Gating results shown in Additional file 1: Figures S1 and Additional file 2: Figure S2.

\section{Tissue immunohistochemistry}

Cadaveric pancreas wedge biopsies frozen at $-80{ }^{\circ} \mathrm{C} 1-5 \mathrm{~h}$ post mortem and cultured exocrine tissue were embedded in OCT mounting media (Tissue-Tek, Sakura, Torrence, CA, USA) then snap frozen in a dry ice/2-methylbutane bath. Tissues were stored at $-80{ }^{\circ} \mathrm{C}$ and sectioned as soon as possible after embedding. Eight micron frozen sections were fixed for $5 \mathrm{~min}$ in $4 \%$ paraformaldehyde in PBS, quenched for $5 \mathrm{~min}$ in $50 \mathrm{mM}$ glycine in PBS then blocked in $5 \%$ donkey serum (Jackson ImmunoResearch, West Grove, PA, USA), 1 \% BSA, 0.1 \% Triton-X100 in PBS for $30 \mathrm{~min}$ at room temperature. Detection of NGN3 was carried out with a mouse monoclonal antibody (Developmental Studies Hybridoma Bank, Iowa city, IA, USA F25A1B3 hybridoma supernatant, 1:10) or rabbit polyclonal antibody (Sigma St. Lois, MO, USA Prestige HPA039785, 1:500). TRKB-T1 isoform was detected using a rabbit polyclonal antibody (Santa Cruz, Santa Cruz, CA, USA Sc-119, 1:250). Secondary antibodies were donkey antisera to the primary antibody conjugated to Alexa Fluor- 488 or -546 (Invitrogen, Carlsbad, CA, USA) and counterstained with Hoechst 33342 (Invitrogen, Carlsbad, CA, USA) to visualize nuclei.

Quantitative immunohistochemistry was carried out by imaging 10 random fields (technical replicates) of $>200$ nuclei per field spanning >100 microns of tissue depth for each treatment group. Fields were captured with Metamorph morphometry software (Metamorph, Sunnyvale, CA, USA) and nuclei were counted using ImageJ image analysis software (http://imagej.nih.gov) blinded to treatment. Some drug treatment studies were carried out independently but are shown together. Significance was determined using a two-tailed homoscedastic Student's $t$-test between drug and carrier control for single drug studies and using a one-way ANOVA with Bonferroni post hoc testing for multiple drug studies. Sample size (n) refers to biological replicate exocrine cultures. Results were reported as mean \pm SEM (standard error of the mean) of technical and biological replicates.

\section{Western blot analyses}

Western blots were incubated in Li-cor blocking solution (Li-cor Bioscience, Lincoln, NE, USA) $1 \mathrm{~h}$ at room temperature then stained with primary antibodies in $5 \%$ BSA, PBS, $0.1 \%$ Triton-X100 overnight at $4{ }^{\circ} \mathrm{C}$. Antibodies and dilutions were: total AKT (Cell Signaling, Beverly, MA, USA \#9272, 1:1000), p(S473)AKT (Cell Signaling, Beverly, MA, USA \#4060, 1:1000), total ERK1/ 2 (Cell Signaling, Beverly, MA, USA \#4695, 1:1000), p(T202/Y204) ERK1/2 (Cell Signaling, Beverly, MA, USA \#4370, 1:1000), GAPDH (Millipore, Billerica, MA, USA MAB374, 1:5000), pan-TRKB (R\&D Systems, Minneapolis, MN, USA MAB3971, 1:250), TRKB-T1 (Santa Cruz, Santa Cruz, CA, USA SC-119, 1:1000). Bound proteins were detected with goat anti-mouse or goat anti-rabbit secondary antibodies conjugated to Dylite-680 or Dylite-800 (Thermo Fisher Scientific, 
Waltham, MA, USA) diluted 1:10,000 in Li-cor blocking buffer (Li-cor Bioscience, Lincoln, NE, USA) with $0.1 \%$ Tween-20, $0.05 \%$ sodium dodecyl sulfate at $25{ }^{\circ} \mathrm{C}$ for 1 $\mathrm{h}$ then imaged on an Odyssey infrared imager (Li-cor Bioscience, Lincoln, NE, USA). For quantification of western blot results, a Student's $t$-test $(n=3)$ was performed on band intensities following staining with anti$\mathrm{p}$ (S473)AKT divided by band intensities following staining with total AKT.

\section{Quantitative RTPCR}

RNA from cultured exocrine tissue and isolated cells were prepared using the RNeasy miniprep kit (Qiagen, Venlo, Netherlands). cDNA was synthesized using oligo(dT) primers in a standard reverse transcriptase reaction with 5 $\mu g$ RNA. mRNA levels were determined by using TaqMan gene expression assays (Applied Biosystems, Foster City, CA, USA): NGN3 (Hs01875204_s1), Pan-TRKB (Hs00178811_m1), TRKB-FL (Hs01093096_m1), TRKBT1 (Hs01093110_m1), HES1 (Hs00172878_m1), KI-67 (Hs01032443_m1) and primer-attenuated cyclophillin A (PPIA, 4310883E). Expression was calculated as mean \pm SEM $2_{t}^{-\Delta \Delta C}$ of 5 technical replica readings for each biological replicate exocrine culture. Each technical replica reaction had approximately $50 \mathrm{ng}$ cDNA template. TRKB expression was normalized to PPIA and expressed as percent of total TRKB level, which was determined separately for exocrine tissue and isolated cells. A mean threshold cycle $\left(C_{t}\right)$ of $>35$ was treated as no expression.

\section{Transcriptome analyses}

Random-primed cDNA from CD133+ and CD133depleted populations $(n=3$ biological replicate exocrine cultures) were subjected to $>20$ million DNA sequencing reads per sample on an HiSeq2000 (Illumina, San Diego, CA, USA) sequencing system then analyzed using the TopHat-Cufflinks-Cuffdiff workflow [32]. Sequencing data was mapped with TopHat (v2.0.5) against the UCSC hg19 reference assembly and viewed using the Integrated Genome Viewer (IGV, broadinstitute.org). Sashimi plot analysis was carried out using IGV to quantify TRKB exon splicing from the transcriptome dataset. Transcriptome data is accessible at the NCBI Gene Expression Omnibus through accession number GSE64854. Neurotrophin pathway activity analysis was done using CummeRbund analysis software [33]. The neurotrophin pathways list is comprised of 320 genes directly involved in neurotrophin signaling or downstream targets curated from the PathCards database (Weizmann Institute of Science, pathcards.genecards.org), SA Biosciences RT2 array list (sabiosciences.com) and the Broad Institute Molecular Signatures Database (MSigDB, broadinstitute.org). Neurotrophin pathway activity score was calculated as the percentage of genes that were upregulated or down regulated by more than 2-fold / the number of genes on the list of 320 that were expressed. Pathway score significance (p) was determined by a one sample two-tailed Student's $t$-test against 10 scores from randomly selected and equally sized gene lists matched to the expression dataset.

\section{Results}

NGN3+ exocrine cells coexpress TRKB and CD133

TRKB and NGN3 were expressed by a mean \pm SEM of $28.2 \pm 4.3 \%$ and $28.2 \pm 4.4 \%$ of cells, respectively, in three biological replicate primary cultures of adult human exocrine tissue. In a representative culture, $35.8 \%$ and $36.5 \%$ of cells were positive for NGN3 and TRKB, respectively and approximately $99 \%$ of cells coexpressed both proteins (Fig. 1a-d). NGN3+ cells can be isolated from human exocrine tissue by immunomagnetic selection for coexpressed cell surface marker CD133 [5]. In a representative culture, $28.2 \%$ and $30.8 \%$ of cells were positive for $\mathrm{CD} 133+$ and $\mathrm{TRKB}+$, respectively and there was approximately $95 \%$ coexpression of both proteins (Fig. 1e-h) (FACS controls and gating strategies in Additional file 1: Figure S1 and Additional file 2: Figure S2). Coexpression results were replicated in two additional exocrine cultures. Taken together with an approximately 270-fold enrichment of TRKB mRNA in isolated NGN3+/CD133+ cells compared to the NGN3D/CD133D population [5], these FACS results demonstrate extensive expression of TRKB by NGN3+/CD133+ cells in cultured adult human exocrine tissue.

\section{NGN3+ exocrine cells express the TRKB-T1 isoform}

Transcriptome analyses and quantitative RTPCR were used to identify TRKB isoform expression in cultured exocrine tissue. Abundant transcription, as indicated by peak height and number of reads joining each exon, of TRKB-T1-specific exon 16 and low level expression of TRKB-FL exons 17-24 in each of three biological replicate NGN3+/CD133+ cell transcriptomes demonstrate that TRKB-T1 is the predominant mRNA transcript expressed in this population. Transcription of alternate exons $5 \mathrm{c}$ and 19 indicate low levels of TRKB-N-T1 [23] and TRKB-T-Shc isoforms, respectively (Fig. 2a).

Isoform-specific quantitative RTPCR was used to quantify the relative transcription levels of total TRKB, TRKB-FL and TRKB-T1. TRKB-T1 expression was significantly higher than TRKB-FL in three biological replicate exocrine cultures $(p=0.01)$ (Fig. $2 \mathrm{~b})$ and in three biological replicate paired NGN3+/CD133+ and NGN3D/ CD133D cell populations ( $p=0.03$ ) (Fig. 2c) in agreement with transcriptome analyses. The expression level of TRKB by NGN3D/CD133D cells was too low to be 


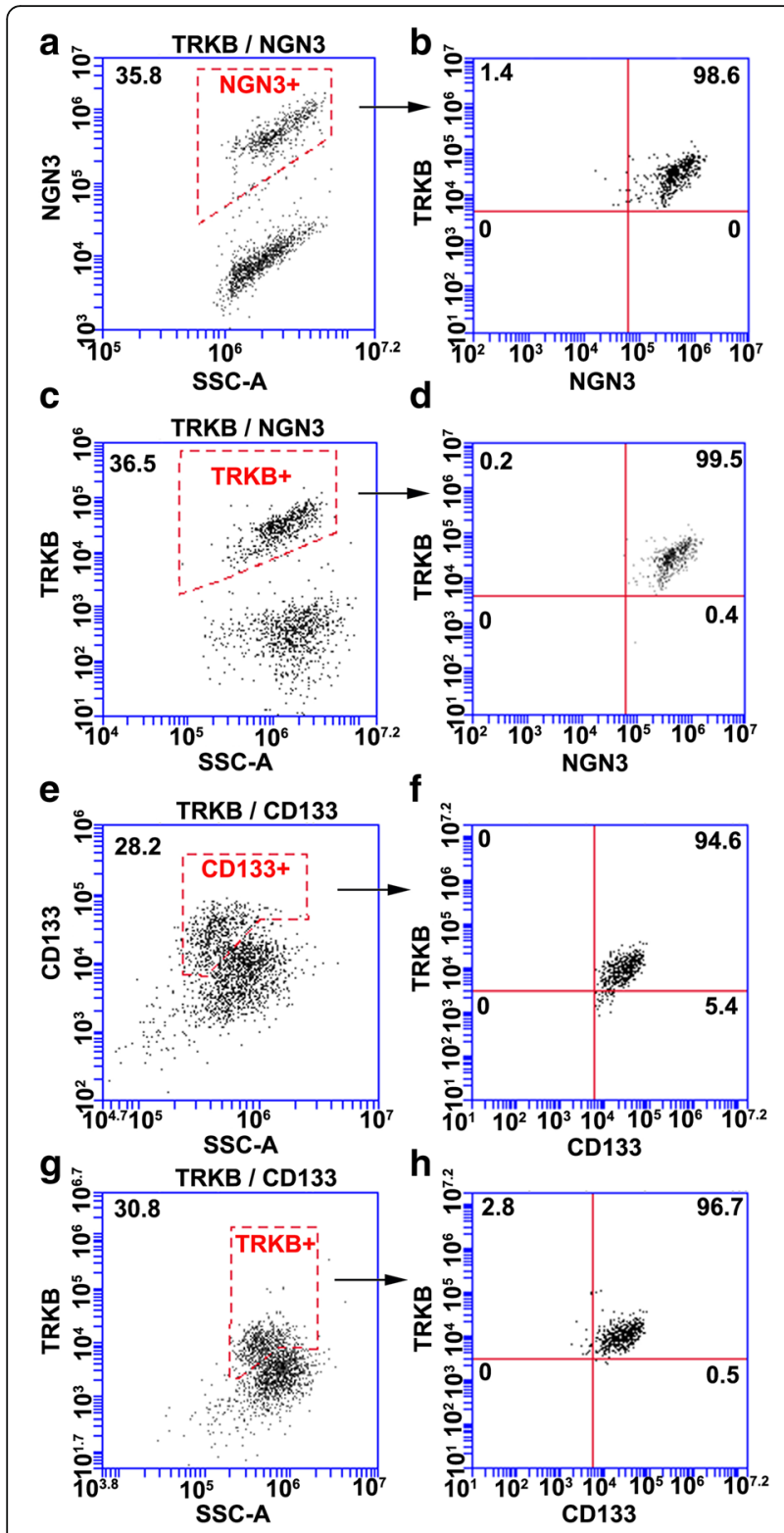

Fig. 1 FACS analysis of neurotrophic tyrosine kinase receptor type 2 (TRKB) expression in cultured human exocrine tissue. Single cells from a primary suspension culture of adult human exocrine tissue were stained with anti-TRKB and anti-mouse Alexa Fluor-647 then fixed, permeabilized and stained with anti-NGN3 (a-d). a NGN3+ population gated based on isotype negative control. $\mathbf{b}$ TRKB/NGN3 coexpression of population gated in a. c TRKB+ population gated based on isotype negative control. d TRKB/NGN3 coexpression of population gated in $\mathbf{c}$. Single cells from a biological replicate exocrine tissue culture were stained with anti-TRKB and anti-mouse Alexa Fluor-647 then stained with anti-CD133-PE (phycoerythrin) (e-h) e CD133+ population gated based on isotype negative control. f TRKB/CD133 coexpression of population gated in e. $\mathbf{g}$ TRKB+ population gated based on isotype negative control. $\mathbf{h}$ TRKB/ CD133 coexpression of population gated in $\mathbf{g}$. Antibody combination shown above plots. Gates shown with dashed and solid red lines. Percentage of cells in each gate are shown in upper corner detected by transcriptome or quantitative RTPCR analyses (mean $\mathrm{C}_{\mathrm{t}}>35$ cycles).

Multiple TRKB isoforms also were observed in western blot analyses of protein lysates from three biological replicate exocrine cultures as well as lysates from paired NGN3+/CD133+ and NGN3D/CD133D cell populations. Immunostaining with a pan TRKB-specific antibody detected a weak band at approximately $140 \mathrm{kDa}$, which corresponds to the predicted size of TRKB-FL [34], in exocrine tissue but not isolated cell extracts (labeled FL in Fig. 2d). Human TRKB-T1 has been detected at either $90-95 \mathrm{kDa}[35]$ or $60-70 \mathrm{kDa}[12,23]$. A band corresponding to the larger TRKB-T1 variant or to TRKB-T-Shc [23] (labeled $\mathrm{T} 1^{\mathrm{L}}$ in Fig. $2 \mathrm{~d}$,e) can be detected in exocrine tissue, NGN3+/CD133+ and to a lesser extent NGN3D/CD133D cell lysates, while the smaller variant (labeled $\mathrm{T}^{\mathrm{S}}$ in Fig. $2 \mathrm{~d}$,e) was weakly detected in NGN3+/CD133+, but not NGN3D/CD133D cell extract (Fig. 2d). Western blot analysis using a TRKB-T1-specific antibody identified a band migrating at approximately $37 \mathrm{kDa}$, which corresponds to the predicted molecular weight of TRKB-N-T1 (Fig. 2e), and confirmed the presence of both TRKB-T1 size variants in protein lysates from three biological replicate exocrine tissue cultures and a single paired set of NGN3+/CD133+ cell extracts. Western blot results using pan TRKB and TRKB-T1 specific antibodies were replicated in a second paired set of isolated cell extracts. Expression of TRKB-T1 by NGN3+ cells was also detected in four biological replicate human cadaveric pancreas biopsies (representative images shown in Fig. 2f).

Whereas the TRKB-T1 $1^{\mathrm{S}}$ size variant was enriched in the NGN3+/CD133+ cell population, detection of TRKB-T1 ${ }^{\mathrm{L}}$ in both NGN3+/CD133+ and NGN3D/ CD133D cell extracts conflicts with low or undetectable levels of TRKB detected in the NGN3D/CD133D population by FACS, transcriptome, and quantitative RTPCR. As it is detected in NGN3D/CD133D extract (Fig. 2d sample $\mathrm{D})$, the TRKB-T1 $1^{\mathrm{L}}$ band may reflect non-specific binding or represent a form of TRKB not readily detected in the transcriptome or by PCR and antibody reagents. Irrespective of the identity of this band, these results demonstrate TRKB-T1 mRNA and protein expression by NGN3+/CD133+ cells in exocrine pancreas tissue.

\section{NGN3 protein expression is positively regulated by TRKB signaling}

Drugs that selectively modulate receptor activity were used to determine if NGN3 is regulated by TRKB signaling. The percentage of NGN3+ cells significantly increased to a mean \pm SEM of $170.5 \pm 7.2 \%$ of carrier control $\left(n=3, p=2.6 \times 10^{-6}\right)$ following treatment of 

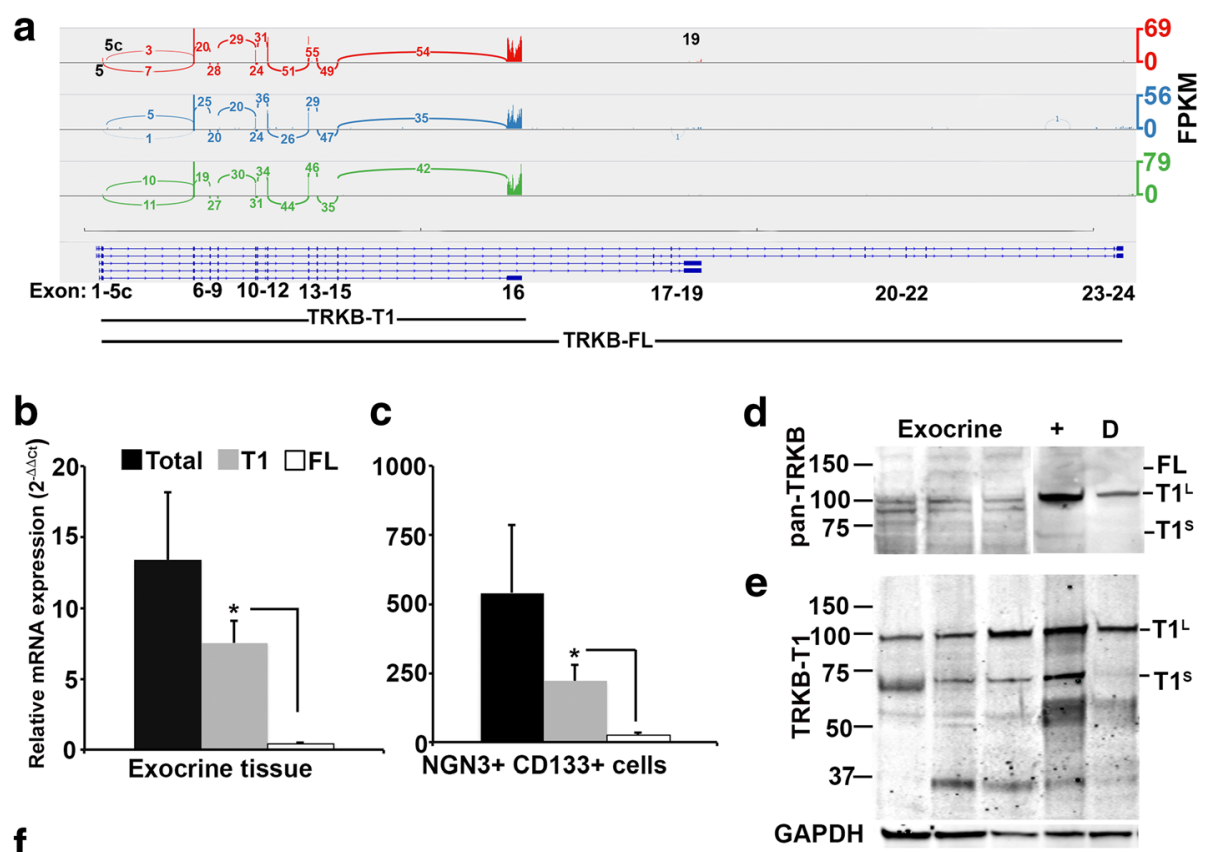

f

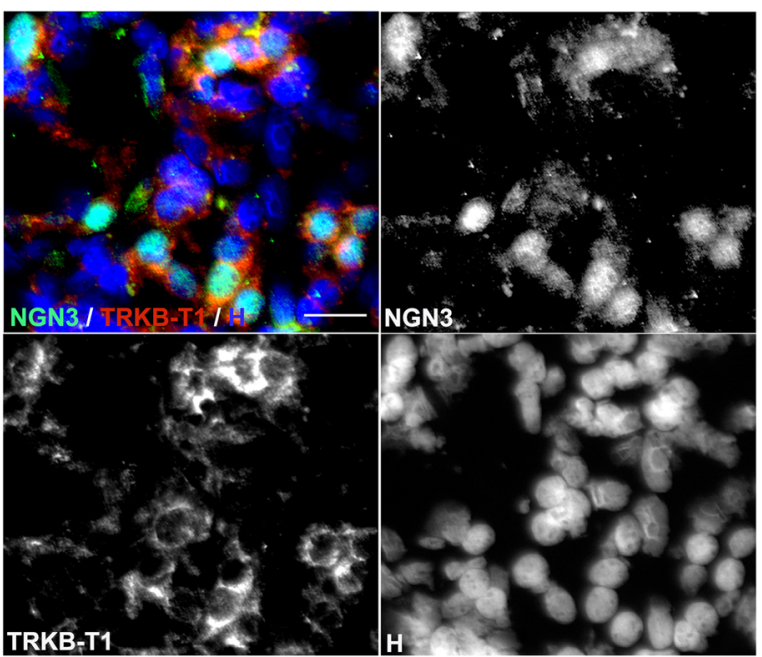

Fig. 2 Quantitative analyses of TRKB isoform expression in cultured human exocrine tissue. a Isoform splicing of the neurotrophic tyrosine kinase receptor type 2 (TRKB) gene by NGN3+ cell populations isolated by coexpression of CD133 from 3 biological replicate exocrine cultures. TRKB loci and major isoforms shown below. Number of reads crossing exons are shown along with lines indicating joined exons. Height of peak indicates relative expression level in fragments per kilobase of transcript per million mapped reads (FPKM). Usage of alternate transcriptional start sites in exons 5 and $5 \mathrm{c}$ and alternate polyadenylation and stop codon in exon 19 are highlighted. $\mathbf{b}, \mathbf{c}$ mRNA levels of total TRKB, TRKB-T1 and TRKB-FL isoforms. Relative Isoform expression calculated as mean \pm SEM ( $n=3$ biological replicate cultures) of $2_{\mathrm{t}}^{-\Delta \Delta C}$ normalized to the level of cyclophillin A (PPIA) in (b) exocrine tissue and (c) NGN3+/CD133+ cells isolated from exocrine tissue. ${ }^{*}, p<0.05$. TRKB levels in NGN3/CD133-depleted exocrine cells were too low to detect. $\mathbf{d}$, e Western blot analyses of TRKB protein isoform expression. Protein lysates from 3 biological replicate exocrine cultures and NGN3+/CD133+ $(+)$ and NGN3/CD133-depleted (D) cells from a single exocrine culture were probed with: d pan TRKB-specific TRKB antibody and (e) TRKB-T1-specific antibody. Apparent molecular mass for TRKB-FL, TRKB-T1 large size variant $\left(\mathrm{T}^{\mathrm{L}}\right)$ and TRKB-T1 small size variant $\left(\mathrm{T}^{\mathrm{S}}{ }^{\mathrm{S}}\right.$ shown at right. Molecular weight markers shown on left in $\mathrm{kDa}$. Level of glyceraldehyde phosphate dehydrogenase (GAPDH) used as loading control. f Representative immunohistochemical staining of human cadaveric pancreas biopsy tissue for expression of NGN3 and TRKB-T1. Color overlay and individual monochrome images are shown with antibodies used. Nuclei counterstained with Hoechst $33342(H)$. Scale bars are 20 microns

exocrine cultures with 7,8-dihydroxyflavone, an agonist that binds the TRKB extracellular domain (Fig. 3a). ANA12, a TRKB ligand that inhibits activation and downstream signaling, significantly decreased the percentage of
NGN3+ cells to $64.9 \pm 5.2 \%$ of carrier control $(n=4$, $\left.p=2.3 \times 10^{-5}\right)$. ANA-12 and 7,8-dihydroxyflavone had no significant effect on NGN3 mRNA expression $(n=3$, $p>0.05)$. These significant and appropriate responses to 


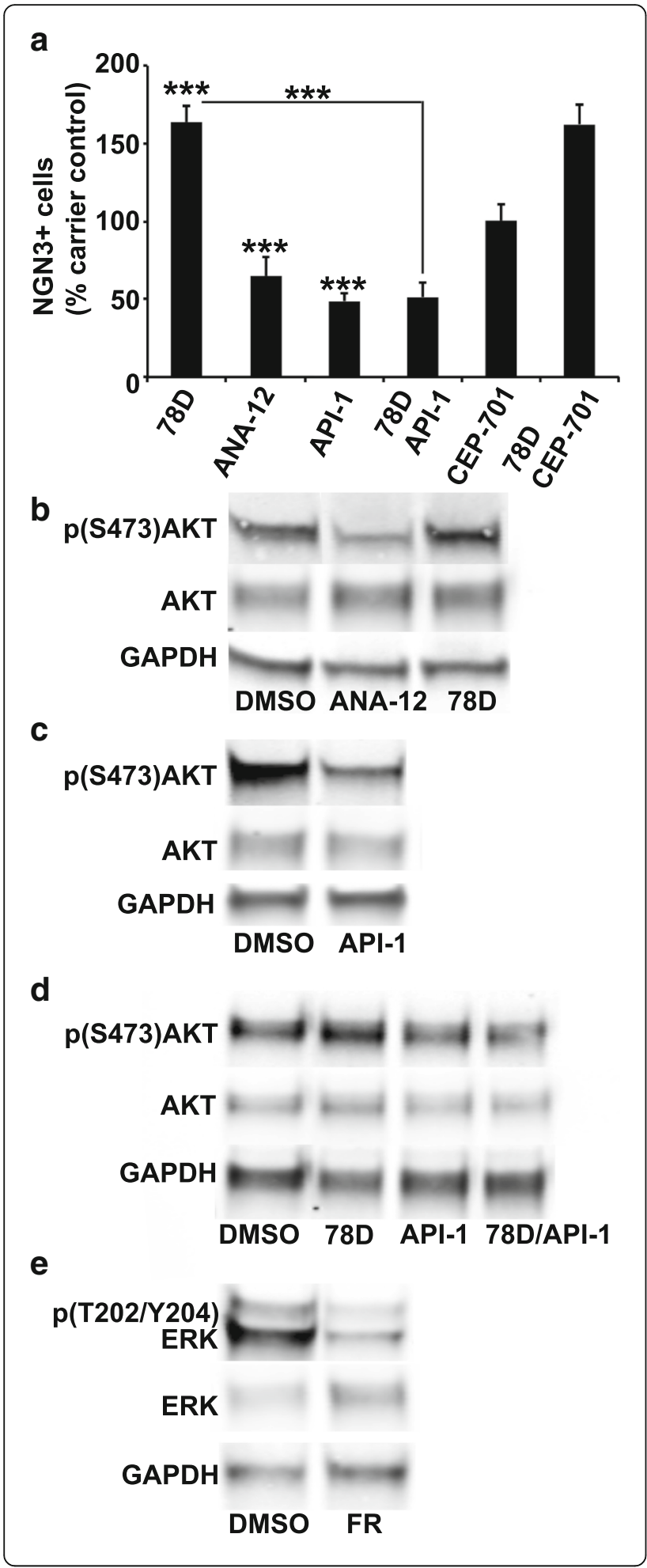

Fig. 3 TRKB regulation of NGN3 in cultured human exocrine tissue. a Percentage of NGN3+ cells in human exocrine tissue cultures treated with Neurotrophic tyrosine kinase type 2 receptor (TRKB) agonist 7,8-dihydroxyflavone (78D, $0.1 \mu \mathrm{M})$, TRKB inhibitor ANA-12 $(50 \mu \mathrm{M})$, protein kinase B (AKT) inhibitor API-1 $(1 \mu \mathrm{M})$, combination of 78D and API-1, tyrosine kinase inhibitor CEP-701 (10 nM) or a combination of 78D and CEP-701 for 4 days. Mean \pm SEM percentage of NGN3+ cells was determined using quantitative immunohistochemistry and normalized to dimethyl sulfoxide (DMSO) carrier control. Significance for ANA-12 determined by two-tailed homoscedastic Student's $t$-test ( $n=10$ technical replica readings from 4 biological replicate exocrine cultures) and for other drugs by one-way ANOVA with Bonferroni post hoc testing ( $n=10$ technical replica readings from 3 biological replicate exocrine cultures), ${ }^{* * *}, p<0.001$. b-d Western blot analyses of signaling activity downstream of TRKB. $\mathbf{b}$ Levels of active protein kinase B ( $p($ (S473)AKT) following treatment with ANA-12 and 78D compared to DMSO carrier control. c Levels of active AKT following treatment with API-1 compared to DMSO carrier control. $\mathbf{d}$ Levels of active ERK1/2 (p(T202/Y204)ERK) following inhibition with FR180204 compared to DMSO carrier control. Protein loading level indicated by level of glyceraldehyde-3-phosphate dehydrogenase (GAPDH) in $\mathbf{b}$-e, total AKT in $\mathbf{b}-\mathbf{d}$ and total ERK in $\mathbf{e}$

TRKB-selective drugs of opposing action strongly suggest NGN3 protein is regulated by TRKB signaling.

AKT is involved in the regulation of NGN3 by TRKB

Western blot analyses were used to determine if TRKB signaling involves changes in the phosphorylation state of AKT. Inhibition of TRKB with ANA-12 decreased AKT activation, as indicated by a decrease in phosphorylation of AKT serine 473 (p(S473)AKT), whereas 7,8dihydroxyflavone increased $\mathrm{p}$ (S473)AKT (Fig. 3b). To determine if $\mathrm{AKT}$ is involved in the regulation of NGN3 by TRKB, exocrine cultures were treated with API-1, a pleckstrin domain-binding AKT inhibitor, alone and in combination with 7,8-dihydroxyflavone. Treatment with API-1 significantly decreased the mean \pm SEM percentage of NGN3+ cells to $48.8 \pm 9.7 \%$ of carrier control $\left(n=3, p=2.4 \times 10^{-4}\right)$ and decreased AKT activation (Fig. 3c). In combination with 7,8-dihydroxyflavone, API-1 blocked the increase in NGN3 observed with 7,8-dihydroxyflavone alone $\left(n=3, p=4.8 \times 10^{-18}\right)$ (Fig. 3a). Similarly, API-1 blocked a significant $(n=3, p=0.01) 7,8$ dihydroxyflavone-dependent increase in AKT activation (representative blot shown in Fig. 3d). In addition to AKT, TRKB also can signal through ERK1/2 [36]. Treatment of exocrine tissue with ERK inhibitor FR180204 decreased ERK1/2 activation, as indicated by a decrease in phosphorylation of ERK1/2 threonine 202 and tyrosine 204 (p(T202/Y204)ERK) (Fig. 3e), but had no effect on the percentage of NGN3+ cells $(n=4$, $p>0.05$, Additional file 3: Figure S3). ANA-12, 7,8dihydroxyflavone and API-1 did not have a significant effect on NGN3 mRNA expression $(n=4, p>0.05$, 
Additional file 4: Figure S4, Additional file 5: Figure S5 and Additional file 6: Figure S6).

To determine if TRKB-FL or other tyrosine kinases were involved in the regulation of NGN3, exocrine tissue was treated with tyrosine kinase inhibitor CEP-701. CEP-701 had no effect on NGN3 protein levels compared to carrier control $(n=3, p>0.05)$ and in combination with 7,8-dihydroxyflavone, did not block the increase in NGN3 observed following treatment with 7,8-dihydroxyflavone alone $(n=3, p>0.05)$ (Fig. 3a). CEP-701 also had no significant effect on NGN3 mRNA expression $(n=3, p>0.05$, Additional file 7 Figure S7). These results demonstrate that AKT is involved in the regulation of NGN3 by TRKB and, in agreement with low levels of TRKB-FL expression, suggest that TRKB tyrosine kinase activity is not required.

TRKB signaling can lead to proliferation and invasiveness of pancreatic adenocarcinoma cell lines [13-15]. While mRNA expression of cellular proliferation antigen Ki-67 and incorporation of 5-ethynyl-2'-deoxyuridine (EdU) both increased during proliferation of isolated NGN3+ cells, there was little evidence of cell proliferation as measured by either technique in cultures of intact exocrine tissue [5] or following pharmacological modulation of TRKB or AKT activity (mean $C_{t}>35$, $n=4$ ). This data, along with coexpression of with NGN3 in histologically normal pancreas biopsies, suggest TRKB signaling results in de novo NGN3 protein accumulation rather than NGN3+ cell proliferation.

NGN3 transcription and protein half-life are regulated by Notch signaling through the transcriptional regulation of repressor hairy and enhancer of split-1 (HES1) [1, 4, 37-39]. Neither TRKB agonist 7,8-dihydroxyflavone nor antagonist ANA-12 had a significant effect on HES1 mRNA levels $(p>0.05, n=4$, Additional file 4: Figures S4, Additional file 5: Figure S5), which suggests regulation of NGN3 by TRKB is independent of canonical HES1mediated Notch signaling.

\section{Differential expression of genes involved in neurotrophin signaling}

The expression level of 320 genes involved in, or regulated by, neurotrophin signaling were analyzed in NGN3+/CD133+ and NGN3/CD133D cell transcriptomes (genes listed in Additional file 8 Table S8). The percentage of genes differentially expressed by more than 2 -fold in the 320 gene set was significantly higher than an equal sized collection of genes randomly selected from the expression dataset $(n=10, p=0.0001)$. In addition to TRKB itself, this analysis identified 41 genes upregulated and 54 genes down regulated by more than 2-fold in the NGN3+/CD133+ population (Table 1). A 187-fold increase in expression of guanine nucleotide exchange factor 3 (VAV3) suggests involvement of Rho/
Rac GTPases, as VAV3 can function as an intermediate between TRKB signaling and GTPase activation [40-43]. Neural cell adhesion molecule 1 (NCAM1), which is upregulated 184-fold, also is involved in modulation of TRKB signaling [44, 45]. Significant upregulation of these genes suggest possible downstream targets of TRKB signaling in NGN3+ exocrine cells.

\section{Discussion}

TRKB-FL activation results in intrinsic tyrosine kinase activity, adapter protein docking and downstream signal transduction. Low levels of TRKB-FL expression and failure of tyrosine kinase inhibition to block regulation of NGN3 suggest involvement of isoforms TRKB-T1, TRKB-T-Shc or TRKB-N-T1. TRKB-T1 is the predominant isoform expressed in the adult rodent central nervous system [46] and is expressed in pancreatic cancer cell lines, but was not detected in normal human pancreatic tissue or immortalized ductal epithelial cells [12]. However, transcriptome-based gene splicing analysis, isoform-specific quantitative RTPCR, western blot and immunohistochemistry demonstrate TRKB-T1 expression by NGN3+ cells in cultured human exocrine tissue and histologically normal cadaveric pancreas biopsies. Although there is evidence for transcription of TRKBT-Shc and TRKB-N-T1 in the NGN3+/CD133+ cell transcriptome, TRKB-T-Shc lacks an activation domain and functions as a negative regulator of TRKB-FL rather than involving AKT signaling [23]. Cytoplasmic localization of TRKB-N-T1 [23] and absence of domains required for TRKB agonist interaction [47] conflict with observed cell-surface antibody staining and signaling results, and argue against involvement of TRKB-N-T1. Taken together, the expression and signaling results reported here are most consistent with regulation of NGN3 by TRKB-T1. The failure of drug treatments to significantly affect NGN3 mRNA levels suggests that TRKB signaling regulates NGN3 translational efficiency or protein stability.

While NGN3 plays a critical role in endocrine lineage fate commitment during pancreas development, its role in the adult pancreas is largely unknown. Although it cannot be detected in the rodent pancreas, targeted disruption of murine NGN3 has a negative impact on islet function [48]. Upregulation of NGN3 by pancreatic endocrine and exocrine cells dedifferentiated under physiological stress conditions suggest it plays a role in cellular plasticity [49-51]. Given the role of TRKB in neuronal plasticity $[52,53]$, it may similarly participate in the initiation or maintenance of exocrine cell dedifferentiation through positive regulation of NGN3.

Although beta cells within preexisting islets [54-60] have been shown to be the predominant source of regenerating beta cells under normal circumstances and 
Table 1 Transcriptome analysis of neurotrophin signaling in cultured human exocrine tissue

\begin{tabular}{|c|c|c|c|c|c|}
\hline \multicolumn{2}{|c|}{ Upregulated } & \multicolumn{4}{|c|}{ Down regulated } \\
\hline Symbol & Fold & Symbol & Fold & Symbol & Fold \\
\hline NTRK2 & 277.1 & IL6 & 36.4 & EIF4EBP1 & 2.3 \\
\hline VAV3 & 187.6 & KCNN2 & 28.8 & MYC & 2.3 \\
\hline NCAM1 & 184.0 & MEF2C & 19.2 & $\mathrm{SHC1}$ & 2.3 \\
\hline $\mathrm{BCL} 2$ & 42.1 & NRG4 & 18.4 & RGS19 & 2.2 \\
\hline CCND1 & 22.5 & GRIA3 & 17.9 & IL6R & 2.2 \\
\hline PLCG2 & 20.7 & SH3GL2 & 16.8 & MAP2K7 & 2.2 \\
\hline SPP1 & 19.7 & MAP3K5 & 16.7 & GNB2L1 & 2.1 \\
\hline NPY1R & 18.8 & GFRA1 & 15.7 & CDK5R1 & 2.1 \\
\hline RPS6KA5 & 10.4 & GDNF & 15.4 & PIK3R3 & 2.1 \\
\hline CNR1 & 9.4 & KSR1 & 14.7 & HSPB1 & 2.0 \\
\hline TGFA & 7.1 & GRPR & 14.0 & RPS6 & 2.0 \\
\hline NCF2 & 5.5 & TGFB1 & 12.6 & EGR2 & 2.0 \\
\hline IRAK2 & 5.5 & GMFG & 11.7 & & \\
\hline TRO & 5.2 & UCN & 11.6 & & \\
\hline IRS2 & 5.1 & IRAK3 & 11.1 & & \\
\hline DOK5 & 4.9 & RAB3A & 8.0 & & \\
\hline MAPK10 & 4.3 & NPFFR2 & 6.8 & & \\
\hline NCK2 & 4.2 & PIK3CG & 5.8 & & \\
\hline FYN & 3.7 & ARHGDIB & 5.0 & & \\
\hline DNM2 & 3.3 & CBLN1 & 5.0 & & \\
\hline RIT1 & 3.0 & IL10RA & 4.9 & & \\
\hline NFKBIE & 2.9 & $\mathrm{SH} 2 \mathrm{~B} 3$ & 4.4 & & \\
\hline MT3 & 2.9 & LIFR & 4.3 & & \\
\hline SHC4 & 2.7 & NELL1 & 3.8 & & \\
\hline DPYSL2 & 2.7 & EEF2 & 3.7 & & \\
\hline GABRB3 & 2.6 & CX3CR1 & 3.6 & & \\
\hline FGF9 & 2.5 & LINGO1 & 3.2 & & \\
\hline DOCK3 & 2.3 & PTGER2 & 3.2 & & \\
\hline ITPR3 & 2.3 & RPS6KA6 & 3.1 & & \\
\hline PIK3R1 & 2.2 & FGFR1 & 3.1 & & \\
\hline SIRPA & 2.2 & STAT5A & 2.9 & & \\
\hline GAB1 & 2.2 & KRAS & 2.8 & & \\
\hline PIK3CD & 2.2 & CRTC1 & 2.8 & & \\
\hline CALM2 & 2.1 & MAPT & 2.7 & & \\
\hline HRAS & 2.1 & FGF2 & 2.6 & & \\
\hline NGFRAP1 & 2.1 & ATF4 & 2.6 & & \\
\hline NCK1 & 2.1 & ELMO1 & 2.5 & & \\
\hline PRKCZ & 2.1 & AP2A1 & 2.5 & & \\
\hline DYNLT1 & 2.1 & MAPK11 & 2.5 & & \\
\hline
\end{tabular}

Table 1 Transcriptome analysis of neurotrophin signaling in cultured human exocrine tissue (Continued)

\begin{tabular}{llll}
\hline DNAL4 & 2.1 & JAK2 & 2.4 \\
MAP3K1 & 2.0 & STAT5B & 2.4 \\
AKT3 & 2.0 & MAP2K2 & 2.3 \\
\hline
\end{tabular}

Transcriptome data from paired NGN3+/CD133+ and NGN3/CD133-depleted cell populations isolated from 3 biological replicate exocrine cultures. Data was analyzed for expression of 320 genes annotated as being involved with, or downstream of, neurotrophin signaling (full gene list in Additional file 8: Table 58). Gene symbol, name and fold expression in NGN3+/CD133+ cells are shown ranked by fold expression compared to NGN3/CD133-depleted cells. Genes discussed shown in bold. Only genes with $a \geq 2$-fold difference are shown

following certain types of pancreatic injury [54-59], it is becoming increasingly evident that pancreatic exocrine cells can be reprogrammed to an endocrine cell fate. Exocrine cells have the capacity to generate insulinexpressing cells following injury and in vitro manipulation [61-70]. Transient expression of NGN3 through adenoviral transduction [71-73], partial duct ligation [74, 75], $90 \%$ pancreatectomy [76, 77], in vivo delivery of cytokines [78, 79] and stabilization of NGN3 protein through knockout of GSK3 $\beta$ [76] or the E3 ubiquitin ligase FBXW7 [80] demonstrate that exocrine cells in the adult pancreas have the capacity to take on an endocrine cell fate and strongly suggest a role for NGN3 in this process. In this regard, pharmacological control of NGN3 through TRKB signaling may represent an innovative approach to the treatment of diabetes.

\section{Conclusion}

Approximately $30 \%$ of total and $95 \%$ of NGN3+ cells in primary cultures of adult human exocrine pancreas tissue expresses TRKB. TRKB-T1, which lacks a tyrosine kinase domain, is the predominant isoform expressed in cultured human exocrine tissue and is expressed in histologically normal cadaveric pancreas biopsies. TRKB signaling positively regulates NGN3 independent of tyrosine kinase activity in cultured adult human exocrine tissue without significantly affecting NGN3 mRNA levels. Identification of VAV3 overexpression in the NGN3+ cell transcriptome suggests TRKB signaling may also involve Rho/Rac GTPases.

\section{Additional files}

Additional file 1: Figure S1. TRKB/NGN3 FACS gating strategy and controls. All FACS analyses used to determine the coexpression of TRKB and NGN3 presented in Fig. 1a-d. (PDF $2250 \mathrm{~kb}$ )

Additional file 2: Figure S2. TRKB/CD133 FACS gating strategy and controls. All FACS analyses used to determine the coexpression of TRKB and CD133 presented in Fig. 1e-h. (PDF 2833 kb)

Additional file 3: Figure S3. Level of NGN3 protein following inhibition of ERK1/2. Results of quantitative immunohistochemistry following treatment of four biological replicate samples (A-D) of exocrine tissue 
with DMSO or ERK1/2 inhibitor FR180204 for four days. Mean and standard error of the mean (SEM) shown as a percentage of total nuclei (\%NGN3) and as percentage of DMSO control (\% control). Mean and SEM of \% control and results of Student's t-test (TTEST) performed on \%NGN3 indicated at right. (DOCX $48 \mathrm{~kb}$ )

Additional file 4: Figure S4. Expression of NGN3 and hairy and enhancer of split-1 (HES1) mRNA following treatment with TRKB antagonist ANA-12. Quantitative RTPCR results of four biological replicate samples (A-D) treated with ANA-12 for four days. RQ, relative quantification of NGN3 and HES1 normalized to the level of cyclophillin A. $\Delta \mathrm{Ct}$, change in threshold cycle $(\mathrm{Ct})$. Mean and standard error of the mean (SEM), results of Student's t-test (TTEST) and percentage of control are shown. (DOCX $50 \mathrm{~kb}$ )

Additional file 5: Figure S5. Expression of NGN3 and hairy and enhancer of split-1 (HES1) mRNA following treatment with TRKB agonist 7,8 dihydroxyflavone (78D). Quantitative RTPCR results of four biological replicate samples (A-D) treated with $78 \mathrm{D}$ for four days. RQ, relative quantification of NGN3 and HES1 normalized to the level of cyclophillin A. $\Delta \mathrm{Ct}$, change in threshold cycle (Ct). Mean and standard error of the mean (SEM), results of Student's t-test (TTEST) and percentage of control are shown. (DOCX $50 \mathrm{~kb}$ )

Additional file 6: Figure S6. Expression of NGN3 and hairy and enhancer of split-1 (HES1) mRNA following treatment with AKT inhibitor API-1. Quantitative RTPCR results of four biological replicate samples (A-D) treated with API-1 for four days. RQ, relative quantification of NGN3 and HES1 normalized to the level of cyclophillin A. $\Delta \mathrm{Ct}$, change in threshold cycle (Ct). Mean and standard error of the mean (SEM), results of Student's $t$-test (TTEST) and percentage of control are shown. (DOCX $49 \mathrm{~kb}$ )

Additional file 7: Figure S7. Expression of NGN3 and hairy and enhancer of split-1 (HES1) mRNA following treatment with tyrosine kinase inhibitor CEP-701. Quantitative RTPCR results of four biological replicate samples (A-D) treated with API-1 for four days. RQ, relative quantification of NGN3 and HES1 normalized to the level of cyclophillin A. $\Delta C \mathrm{Ct}$, change in threshold cycle $(\mathrm{Ct})$. Mean and standard error of the mean (SEM), results of Student's $t$-test (TTEST) and percentage of control are shown. (DOCX $47 \mathrm{~kb})$

Additional file 8: Table S8. Genes involved with neurotrophin signaling. List of 320 genes annotated as being involved with, or downstream of, neurotrophin signaling. (DOCX $148 \mathrm{~kb}$ )

\section{Abbreviations}

AKT: Protein kinase B; ANA-12: N-[2-[[(Hexahydro-2-oxo-1H-azepin-3yl)amino]carbonyl]phenyl]benzo[b]thiophene-2-carboxamide; ANOVA: Analysis of variance; API-1: 4-Amino-5,8-dihydro-5-oxo-8- $\beta-D-$ ribofuranosyl-pyrido[2,3-d]pyrimidine-6-carboxamide; BSA: Bovine serum albumin; CEP-701: (9S, 10S,12R)-2,3,9,10,11,12-Hexahydro-10-hydroxy-10(hydroxymethyl)-9-methyl-9,12-epoxy-1H-diindolo[1,2,3-fg:3',2',1'kl]pyrrolo[3,4-i][1, 6]benzodiazocin-1-one; DMSO: Dimethyl sulfoxide; EDTA: Ethylenediaminetetraacetic acid; EdU: 5-ethynyl-2'-deoxyuridine; ERK: Extracellular signal related kinase; FACS: Fluorescence activated cell sorting. $C_{\mathrm{t}}$, threshold cycle; FR180204: 5-(2-Phenyl-pyrazolo[1,5-a]pyridin-3-yl)$1 \mathrm{H}$-pyrazolo[3,4-c]pyridazin-3-ylamine; HES1: Repressor hairy and enhancer of split-1; kDa: Kilodalton; NCAM1: Neural cell adhesion molecule 1; NGN3: Neurogenin 3; PBS: Phosphate buffered saline; PE: Phycoerythrin; PPIA: cyclophillin A; RTPCR: Reverse transcriptase polymerase chain reaction; TRKB: Neurotrophic tyrosine kinase receptor type 2; VAV3: Guanine nucleotide exchange factor 3

\section{Acknowledgements}

Exocrine and islet tissue was obtained through the ICR Basic Science Islet Distribution Program (IIDP) sponsored by the National Institutes of Health National Center for Research Resources (NCRR), National institute of Diabetes and Digestive and Kidney Diseases (NIDDK). The anti-NGN3 monoclonal antibody was obtained from the Developmental Studies Hybridoma Bank developed under the auspices of the NICHD and maintained by the University of lowa, Department of Biological Sciences. We thank Aneesha Khatari, Genevieve Tuite and Bailey Perez for help with immunochemistry as well as Christina Dempsey and Shea Smith for editorial assistance.

\section{Funding}

The main source of funding for this work came from The University of South Florida/All Children's Foundation Sam's Club/Walmart Chair of Pediatrics (MJS). These funds were given as a gift by associates and customers of Sam's Club and Walmart. It did not involve any additional employment, consultancy, intellectual property licensing, product development or marketing. Additional funding was received from the Juvenile Diabetes Research Foundation (www.jdrforg) grant number 2-2008-65 (MJS) and gifts from the Mayhew Family (MJS), Chicago Diabetes Project (MJS) and John Horst (MJS). The funders had no role in study design, data collection and analysis, decision to publish, or preparation of the manuscript.

\section{Availability of data and materials}

The dataset supporting the conclusions of this article are available in the NCBI Gene Expression Omnibus (http://www.ncbi.nlm.nih.gov/geo/) repository through the accession number GSE64854.

\section{Authors' contributions}

MJS designed, performed and analyzed experiments, supervised the study and wrote the manuscript; MLO, DLG and DLM performed and analyzed experiments and contributed to writing the manuscript. All authors read and approved the manuscript.

\section{Competing interests}

Under a licensing agreement between National Stem Cell, Inc. and the Johns Hopkins University, Dr. Shamblott is entitled to a share of royalty received by the University on sales of products/technologies described in this article. The terms of this arrangement are being managed by Johns Hopkins University in accordance with its conflict of interest policies. No part of this agreement limits the sharing and distribution of research materials. The other authors have no competing financial interests.

\section{Consent for publication}

No personal identifiers were used in this study.

\section{Ethics approval and consent to participate}

Exocrine tissue isolated from human pancreata of non-diabetic adult cadaver donors were obtained from ICR Basic Science Islet Distribution Program (IIDP) under the auspices of the National Institutes of Health National Center for Research Resources (NCRR). Written informed consent for research use was obtained by the institutions that collected the tissue. Tissues were received without personal identifiers. Based on the regulatory definition of human subject research, this study was granted an IRB exemption by the University of South Florida Institutional Review Board (FWA 00001669), review date 5/10/2011.

Received: 12 April 2016 Accepted: 14 September 2016

Published online: 22 September 2016

\section{References}

1. Lee JC, Smith SB, Watada H, Lin J, Scheel D, Wang J, Mirmira RG, German MS. Regulation of the pancreatic pro-endocrine gene neurogenin3. Diabetes. 2001;50(5):928-36.

2. Sarkar SA, Kobberup S, Wong R, Lopez AD, Quayum N, Still T, Kutchma A, Jensen JN, Gianani R, Beattie GM, Jensen J, Hayek A, Hutton JC. Global gene expression profiling and histochemical analysis of the developing human fetal pancreas. Diabetologia. 2008;51(2):285-97.

3. Gradwohl G, Dierich A, LeMeur M, Guillemot F. Neurogenin3 is required for the development of the four endocrine cell lineages of the pancreas. Proc Natl Acad Sci U S A. 2000;97(4):1607-11

4. Apelqvist A, Li H, Sommer L, Beatus $P$, Anderson DJ, Honjo $T$, Hrabe de Angelis $\mathrm{M}$, Lendahl $\mathrm{U}$, Edlund $\mathrm{H}$. Notch signalling controls pancreatic cell differentiation. Nature. 1999;400(6747):877-81.

5. Gomez DL, O'Driscoll M, Sheets TP, Hruban RH, Oberholzer J, McGarrigle JJ, Shamblott MJ. Neurogenin 3 Expressing Cells in the Human Exocrine Pancreas Have the Capacity for Endocrine Cell Fate. PloS ONE. 2015;10(8):e0133862.

6. Huang EJ, Reichardt LF. Trk receptors: roles in neuronal signal transduction. Annu Rev Biochem. 2003;72:609-42.

7. Kaplan DR, Miller FD. Neurotrophin signal transduction in the nervous system. Curr Opin Neurobiol. 2000;10(3):381-91. 
8. McAllister AK, Katz LC, Lo DC. Neurotrophins and synaptic plasticity. Annu Rev Neurosci. 1999;22:295-318.

9. Shelton DL, Sutherland J, Gripp J, Camerato T, Armanini MP, Phillips HS, Carroll K, Spencer SD, Levinson AD. Human trks: molecular cloning, tissue distribution, and expression of extracellular domain immunoadhesins. J Neurosci. 1995;15(1 Pt 2):477-91.

10. Schneider MB, Standop J, Ulrich A, Wittel U, Friess H, Andren-Sandberg A, Pour PM. Expression of nerve growth factors in pancreatic neural tissue and pancreatic cancer. J Histochem Cytochem. 2001;49(10):1205-10.

11. Sclabas GM, Fujioka S, Schmidt C, Li Z, Frederick WA, Yang W, Yokoi K, Evans DB, Abbruzzese JL, Hess KR, Zhang W, Fidler IJ, Chiao PJ. Overexpression of tropomysin-related kinase $B$ in metastatic human pancreatic cancer cells. Clin Cancer Res. 2005;11(2 Pt 1):440-9.

12. Li Z, Chang Z, Chiao LJ, Kang Y, Xia Q, Zhu C, Fleming JB, Evans DB, Chiao PJ. TrkBT1 induces liver metastasis of pancreatic cancer cells by sequestering Rho GDP dissociation inhibitor and promoting RhoA activation. Cancer Res. 2009;69(19):7851-9.

13. Miknyoczki SJ, Dionne CA, Klein-Szanto AJ, Ruggeri BA. The novel Trk receptor tyrosine kinase inhibitor CEP-701 (KT-5555) exhibits antitumor efficacy against human pancreatic carcinoma (Panc1) xenograft growth and in vivo invasiveness. Ann N Y Acad Sci. 1999;880:252-62.

14. Miknyoczki SJ, Lang D, Huang L, Klein-Szanto AJ, Dionne CA, Ruggeri BA. Neurotrophins and Trk receptors in human pancreatic ductal adenocarcinoma: expression patterns and effects on in vitro invasive behavior. Int J Cancer. 1999;81(3):417-27.

15. Li Z, Peng B, Evans DB, Chiao J. A novel mechanism for overexpression of TRKB-T1-induced pancreatic cancer metastasis. Pancreas. 2007:35(4):293-440.

16. Stoilov P, Castren E, Stamm S. Analysis of the human TrkB gene genomic organization reveals novel TrkB isoforms, unusual gene length, and splicing mechanism. Biochem Biophys Res Commun. 2002;290(3):1054-65.

17. Reichardt LF. Neurotrophin-regulated signalling pathways. Philos Trans R Soc Lond B Biol Sci. 2006;361(1473):1545-64.

18. Johnson-Farley NN, Travkina T, Cowen DS. Cumulative activation of akt and consequent inhibition of glycogen synthase kinase-3 by brain-derived neurotrophic factor and insulin-like growth factor-1 in cultured hippocampal neurons. J Pharmacol Exp Ther. 2006;316(3):1062-9.

19. Slack SE, Grist J, Mac Q, McMahon SB, Pezet S. TrkB expression and phospho-ERK activation by brain-derived neurotrophic factor in rat spinothalamic tract neurons. J Comp Neurol. 2005;489(1):59-68.

20. Ji Y, Lu Y, Yang F, Shen W, Tang TT, Feng L, Duan S, Lu B. Acute and gradual increases in BDNF concentration elicit distinct signaling and functions in neurons. Nat Neurosci. 2010;13(3):302-9.

21. Gruart A, Sciarretta C, Valenzuela-Harrington M, Delgado-Garcia JM, Minichiello L. Mutation at the TrkB PLC\{gamma\}-docking site affects hippocampal LTP and associative learning in conscious mice. Learn Mem. 2007;14(1):54-62.

22. He XP, Pan E, Sciarretta C, Minichiello L, McNamara JO. Disruption of TrkBmediated phospholipase Cgamma signaling inhibits limbic epileptogenesis. J Neurosci. 2010;30(18):6188-96.

23. Luberg K, Wong J, Weickert CS, Timmusk T. Human TrkB gene: novel alternative transcripts, protein isoforms and expression pattern in the prefrontal cerebral cortex during postnatal development. J Neurochem. 2010;113(4):952-64.

24. Baxter GT, Radeke MJ, Kuo RC, Makrides V, Hinkle B, Hoang R, Medina-Selby A, Coit D, Valenzuela P, Feinstein SC. Signal transduction mediated by the truncated trkB receptor isoforms, trkB.T1 and trkB.T2. J Neurosci. 1997;17(8):2683-90.

25. Ohira K, Shimizu K, Hayashi M. Change of expression of full-length and truncated TrkBs in the developing monkey central nervous system. Brain Res Dev Brain Res. 1999;112(1):21-9.

26. Klein $R$, Conway D, Parada LF, Barbacid $M$. The trkB tyrosine protein kinase gene codes for a second neurogenic receptor that lacks the catalytic kinase domain. Cell. 1990;61(4):647-56.

27. Biffo S, Offenhauser N, Carter BD, Barde YA. Selective binding and internalisation by truncated receptors restrict the availability of BDNF during development. Development. 1995;121(8):2461-70.

28. Hartmann M, Brigadski T, Erdmann KS, Holtmann B, Sendtner M, Narz F, Lessmann V. Truncated TrkB receptor-induced outgrowth of dendritic filopodia involves the p75 neurotrophin receptor. J Cell Sci. 2004;117(Pt 24):5803-14.

29. Dorsey SG, Renn CL, Carim-Todd L, Barrick CA, Bambrick L, Krueger BK, Ward CW, Tessarollo L. In vivo restoration of physiological levels of truncated TrkB.T1 receptor rescues neuronal cell death in a trisomic mouse model. Neuron. 2006;51(1):21-8.

30. Ohira K, Kumanogoh H, Sahara Y, Homma K, Hirai H, Nakamura S, Hayashi M. A truncated tropomyosin-related kinase B receptor, T1, regulates glial cell morphology via Rho GDP dissociation inhibitor 1. J Neurosci. 2005;25(6):1343-53.

31. Ohira K, Homma KJ, Hirai H, Nakamura S, Hayashi M. TrkB-T1 regulates the RhoA signaling and actin cytoskeleton in glioma cells. Biochem Biophys Res Commun. 2006;342(3):867-74.

32. Trapnell C, Hendrickson DG, Sauvageau M, Goff L, Rinn JL, Pachter L. Differential analysis of gene regulation at transcript resolution with RNA-seq Nat Biotechnol. 2013;31(1):46-53.

33. Trapnell C, Roberts A, Goff L, Pertea G, Kim D, Kelley DR, Pimentel H, Salzberg SL, Rinn JL, Pachter L. Differential gene and transcript expression analysis of RNAseq experiments with TopHat and Cufflinks. Nat Protoc. 2012;7(3):562-78.

34. Hamel W, Westphal M, Szonyi E, Escandon E, Nikolics K. Neurotrophin gene expression by cell lines derived from human gliomas. J Neurosci Res. 1993;34(2):147-57.

35. Wong J, Rothmond DA, Webster MJ, Weickert CS. Increases in two truncated TrkB isoforms in the prefrontal cortex of people with schizophrenia. Schizophr Bull. 2013;39(1):130-40.

36. Ortega F, Perez-Sen R, Morente V, Delicado EG, Miras-Portugal MT. P2X7, NMDA and BDNF receptors converge on GSK3 phosphorylation and cooperate to promote survival in cerebellar granule neurons. Cell Mol Life Sci. 2010;67(10):1723-33.

37. Jensen J, Pedersen EE, Galante P, Hald J, Heller RS, Ishibashi M, Kageyama R, Guillemot F, Serup P, Madsen OD. Control of endodermal endocrine development by Hes-1. Nat Genet. 2000;24(1):36-44.

38. Murtaugh LC, Stanger BZ, Kwan KM, Melton DA. Notch signaling controls multiple steps of pancreatic differentiation. Proc Natl Acad Sci U S A. 2003;100(25):14920-5.

39. Qu X, Afelik S, Jensen JN, Bukys MA, Kobberup S, Schmerr M, Xiao F, Nyeng P, Veronica Albertoni M, Grapin-Botton A, Jensen J. Notch-mediated posttranslational control of Ngn3 protein stability regulates pancreatic patterning and cell fate commitment. Dev Biol. 2013;376(1):1-12.

40. Hale CF, Dietz KC, Varela JA, Wood CB, Zirlin BC, Leverich LS, Greene RW, Cowan CW. Essential role for vav Guanine nucleotide exchange factors in brain-derived neurotrophic factor-induced dendritic spine growth and synapse plasticity. J Neurosci. 2011;31(35):12426-36.

41. Cowan CW, Shao YR, Sahin M, Shamah SM, Lin MZ, Greer PL, Gao S, Griffith EC, Brugge JS, Greenberg ME. Vav family GEFs link activated Ephs to endocytosis and axon guidance. Neuron. 2005;46(2):205-17.

42. Cerione RA, Zheng Y. The Dbl family of oncogenes. Curr Opin Cell Biol. 1996:8(2):216-22.

43. Abe K, Rossman KL, Liu B, Ritola KD, Chiang D, Campbell SL, Burridge K, Der CJ. Vav2 is an activator of Cdc42, Rac1, and RhoA. J Biol Chem. 2000:275(14):10141-9.

44. Kleene R, Cassens C, Bahring R, Theis T, Xiao MF, Dityatev A, Schafer-Nielsen C, Doring F, Wischmeyer E, Schachner M. Functional consequences of the interactions among the neural cell adhesion molecule NCAM, the receptor tyrosine kinase TrkB, and the inwardly rectifying K+ channel KIR3.3. J Biol Chem. 2010;285(37):28968-79.

45. Cassens C, Kleene R, Xiao MF, Friedrich C, Dityateva G, Schafer-Nielsen C, Schachner M. Binding of the receptor tyrosine kinase TrkB to the neural cell adhesion molecule (NCAM) regulates phosphorylation of NCAM and NCAMdependent neurite outgrowth. J Biol Chem. 2010;285(37):28959-67.

46. Cabelli RJ, Allendoerfer KL, Radeke MJ, Welcher AA, Feinstein SC, Shatz CJ. Changing patterns of expression and subcellular localization of TrkB in the developing visual system. J Neurosci. 1996;16(24):7965-80.

47. Jang SW, Liu X, Yepes M, Shepherd KR, Miller GW, Liu Y, Wilson WD, Xiao G, Blanchi B, Sun YE, Ye K. A selective TrkB agonist with potent neurotrophic activities by 7,8-dihydroxyflavone. Proc Natl Acad Sci U S A. 2010;107(6):2687-92.

48. Wang S, Jensen JN, Seymour PA, Hsu W, Dor Y, Sander M, Magnuson MA, Serup P, Gu G. Sustained Neurog3 expression in hormone-expressing islet cells is required for endocrine maturation and function. Proc Natl Acad Sci U S A. 2009;106(24):9715-20.

49. Valdez IA, Teo AK, Kulkarni RN. Cellular stress drives pancreatic plasticity. Sci Transl Med. 2015;7(273):273ps2.

50. Talchai C, Xuan S, Lin HV, Sussel L, Accili D. Pancreatic beta cell dedifferentiation as a mechanism of diabetic beta cell failure. Cell. 2012;150(6):1223-34. 
51. Wang Z, York NW, Nichols CG, Remedi MS. Pancreatic beta cell dedifferentiation in diabetes and redifferentiation following insulin therapy. Cell metabolism. 2014;19(5):872-82.

52. Michaelsen K, Zagrebelsky M, Berndt-Huch J, Polack M, Buschler A, Sendtner M, Korte M. Neurotrophin receptors TrkB.T1 and p75NTR cooperate in modulating both functional and structural plasticity in mature hippocampal neurons. Eur J Neurosci. 2010;32(11):1854-65.

53. Lu B, Nagappan G, Guan X, Nathan PJ, Wren P. BDNF-based synaptic repair as a disease-modifying strategy for neurodegenerative diseases. Nat Rev Neurosci. 2013;14(6):401-16.

54. Dor Y, Brown J, Martinez Ol, Melton DA. Adult pancreatic beta-cells are formed by self-duplication rather than stem-cell differentiation. Nature. 2004:429(6987):41-6.

55. Teta M, Rankin MM, Long SY, Stein GM, Kushner JA. Growth and regeneration of adult beta cells does not involve specialized progenitors. Dev Cell. 2007;12(5):817-26.

56. Nir T, Melton DA, Dor Y. Recovery from diabetes in mice by beta cell regeneration. J Clin Invest. 2007;117(9):2553-61.

57. Brennand K, Huangfu D, Melton D. All beta cells contribute equally to islet growth and maintenance. PLoS Biology. 2007;5(7):e163.

58. Desai BM, Oliver-Krasinski J, De Leon DD, Farzad C, Hong N, Leach SD, Stoffers DA. Preexisting pancreatic acinar cells contribute to acinar cell, but not islet beta cell, regeneration. J Clin Invest. 2007:117(4):971-7.

59. Xiao X, Chen Z, Shiota C, Prasadan K, Guo P, El-Gohary Y, Paredes J, Welsh C, Wiersch J, Gittes GK. No evidence for beta cell neogenesis in murine adult pancreas. J Clin Invest. 2013;123(5):2207-17.

60. Xiao X, Guo P, Shiota C, Prasadan K, El-Gohary Y, Wiersch J, Gaffar I, Gittes GK. Neurogenin3 activation is not sufficient to direct duct-to-beta cell transdifferentiation in the adult pancreas. J Biol Chem. 2013;288(35):25297-308

61. Lipsett M, Finegood DT. Beta-cell neogenesis during prolonged hyperglycemia in rats. Diabetes. 2002;51(6):1834-41.

62. Minami K, Okuno M, Miyawaki K, Okumachi A, Ishizaki K, Oyama K, Kawaguchi M, Ishizuka N, Iwanaga T, Seino S. Lineage tracing and characterization of insulin-secreting cells generated from adult pancreatic acinar cells. Proc Natl Acad Sci U S A. 2005;102(42):15116-21.

63. Baeyens L, De Breuck S, Lardon J, Mfopou JK, Rooman I, Bouwens L. In vitro generation of insulin-producing beta cells from adult exocrine pancreatic cells. Diabetologia. 2005;48(1):49-57.

64. Bonner-Weir S, Baxter LA, Schuppin GT, Smith FE. A second pathway for regeneration of adult exocrine and endocrine pancreas. A possible recapitulation of embryonic development. Diabetes. 1993;42(12):1715-20.

65. Heremans $Y$, Van De Casteele M, In't Veld P, Gradwohl G, Serup P, Madsen O, Pipeleers D, Heimberg $\mathrm{H}$. Recapitulation of embryonic neuroendocrine differentiation in adult human pancreatic duct cells expressing neurogenin 3. J Cell Biol. 2002;159(2):303-12.

66. Bonner-Weir S, Taneja M, Weir GC, Tatarkiewicz K, Song KH, Sharma A, O'Neil JJ. In vitro cultivation of human islets from expanded ductal tissue. Proc Natl Acad Sci U S A. 2000;97(14):7999-8004.

67. Yatoh S, Dodge R, Akashi T, Omer A, Sharma A, Weir GC, Bonner-Weir S. Differentiation of Affinity-Purified Human Pancreatic Duct Cells to \{beta\}Cells. Diabetes. 2007;56(7):1802-9.

68. Kim HS, Hong SH, Oh SH, Kim JH, Lee MS, Lee MK. Activin A, exendin-4, and glucose stimulate differentiation of human pancreatic ductal cells. J Endocrinol. 2013;217(3):241-52.

69. Kerr-Conte J, Pattou F, Lecomte-Houcke M, Xia Y, Boilly B, Proye C, Lefebvre J. Ductal cyst formation in collagen-embedded adult human islet preparations. A means to the reproduction of nesidioblastosis in vitro. Diabetes. 1996;45(8):1108-14.

70. Gao R, Ustinov J, Pulkkinen MA, Lundin K, Korsgren O, Otonkoski T. Characterization of endocrine progenitor cells and critical factors for their differentiation in human adult pancreatic cell culture. Diabetes. 2003;52(8):2007-15.

71. Zhou Q, Brown J, Kanarek A, Rajagopal J, Melton DA. In vivo reprogramming of adult pancreatic exocrine cells to beta-cells. Nature. 2008;455(7213):627-32.

72. Swales N, Martens GA, Bonne S, Heremans Y, Borup R, Van de Casteele M Ling Z, Pipeleers D, Ravassard P, Nielsen F, Ferrer J, Heimberg H. Plasticity of adult human pancreatic duct cells by neurogenin3-mediated reprogramming. PloS one. 2012;7(5):e37055.

73. Gasa R, Mrejen C, Leachman N, Otten M, Barnes M, Wang J, Chakrabarti S, Mirmira R, German M. Proendocrine genes coordinate the pancreatic islet differentiation program in vitro. Proc Natl Acad Sci U S A. 2004;101(36):13245-50.

74. Xu X, D'Hoker J, Stange G, Bonne S, De Leu N, Xiao X, Van de Casteele M, Mellitzer G, Ling Z, Pipeleers D, Bouwens L, Scharfmann R, Gradwohl G, Heimberg $\mathrm{H}$. Beta cells can be generated from endogenous progenitors in injured adult mouse pancreas. Cell. 2008;132(2):197-207.

75. Van de Casteele M, Leuckx G, Baeyens L, Cai Y, Yuchi Y, Coppens V, De Groef S, Eriksson M, Svensson C, Ahlgren U, Ahnfelt-Ronne J, Madsen OD, Waisman A, Dor Y, Jensen JN, Heimberg H. Neurogenin 3+ cells contribute to beta-cell neogenesis and proliferation in injured adult mouse pancreas. Cell Death Dis. 2013;4:e523.

76. Figeac F, llias A, Bailbe D, Portha B, Movassat J. Local in vivo GSK3beta knockdown promotes pancreatic beta cell and acinar cell regeneration in $90 \%$ pancreatectomized rat. Mol Ther. 2012;20(10):1944-52.

77. Li WC, Rukstalis JM, Nishimura W, Tchipashvili V, Habener JF, Sharma A, Bonner-Weir S. Activation of pancreatic-duct-derived progenitor cells during pancreas regeneration in adult rats. J Cell Sci. 2010;123(Pt 16):2792-802.

78. Baeyens L, Lemper M, Leuckx G, De Groef S, Bonfanti P, Stange G, Shemer R, Nord C, Scheel DW, Pan FC, Ahlgren U, Gu G, Stoffers DA, Dor Y, Ferrer J, Gradwohl G, Wright CV, Van de Casteele M, German MS, Bouwens L, Heimberg $H$. Transient cytokine treatment induces acinar cell reprogramming and regenerates functional beta cell mass in diabetic mice. Nat Biotechnol. 2014;32(1):76-83.

79. Baeyens L, Bonne S, German MS, Ravassard P, Heimberg H, Bouwens L. Ngn3 expression during postnatal in vitro beta cell neogenesis induced by the JAK/STAT pathway. Cell Death Differ. 2006;13(11):1892-9.

80. Sancho R, Gruber R, Gu G, Behrens A. Loss of Fbw7 reprograms adult pancreatic ductal cells into alpha, delta, and beta cells. Cell Stem Cell. 2014;15(2):139-53.

\section{Submit your next manuscript to BioMed Central and we will help you at every step:}

- We accept pre-submission inquiries

- Our selector tool helps you to find the most relevant journal

- We provide round the clock customer support

- Convenient online submission

- Thorough peer review

- Inclusion in PubMed and all major indexing services

- Maximum visibility for your research

Submit your manuscript at www.biomedcentral.com/submit

) Biomed Central 